\title{
Environmental Governance and Climate Change Adaptation in Indonesia
}

\author{
Asti Amelia Novita ${ }^{\text {a* }}$ \\ ${ }^{a}$ Universitas Brawijaya, Malang, East Java, Indonesia
}

\section{ARTICLE INFORMATION}

\section{Article history:}

Date Submission: 23 March 2021

First Revision: 28 March 2021

Accepted: 30 March 2021

Available Online: 13 April 2021

Keywords: environmental governance, climate change, adaptation

\section{ABSTRACT}

This paper examines environmental governance in climate change adaptation efforts in Indonesia. Climate Change has been a common concern, especially since the signing of 194 countries in the Paris Agreement. Climate change adaptation is one of the points in the Paris Agreement as an effort to implement commitments to tackle global climate change. Climate change adaptation is one of the responses made by humans in facing climate change in addition to mitigation. Adaptation is carried out to reduce vulnerability to the effects of climate change. The Indonesian government has made various climate change adaptation efforts, including preparing national policy documents such as INDC, RAN-API, and related regulations to address the impacts of climate change. However, the research results show that strengthening climate change adaptation efforts needs to be balanced with commitment from sharing parties, strengthening the role of the private sector, and proper budget planning. Committees here are associated with the alignment of central and regional policies and the compliance of local governments in implementing climate change adaptation policies. The private sector's role emphasized the contribution of activities and finance to climate change adaptation efforts through corporate social responsibility programs.

\section{INTISARI}

Tulisan ini mengkaji tata kelola lingkungan hidup dalam usaha adaptasi perubahan iklim di Indonesia. Perubahan Iklim telah menjadi perhatian bersama khususnya sejak penandatanganan 194 negara dalam Perjanjian Paris. Adaptasi perubahan iklim merupakan salah satu poin yang tertuang dalam Perjanjian Paris sebagai upaya pelaksanaan komitmen terhadap upaya penanganan global perubahan iklim. Adaptasi perubahan iklim merupakan salah satu respon yang dilakukan oleh manusia dalam menghadapi perubahan iklim selain mitigasi. Adaptasi dilakukan untuk mengurangi kerentanan terhadap efek perubahan iklim. Pemerintah Indonesia telah melakukan berbagai upaya adaptasi perubahan iklim, termasuk penyusunan dokumen kebijakan nasional seperti INDC, RAN-API, dan peraturan terkait untuk mengatasi dampak perubahan iklim. Namun demikian hasil penelitian menunjukkan penguatan upaya adaptasi perubahan iklim perlu diimbangi dengan komitmen berbagi pihak, penguatan peran sektor swasta serta perencanaan penganggaran yang baik. Komiten disini dikaitkan dengan keselarasan kebijakan pusat dan daerah serta kepatuhan pemerintah daerah dalam melaksanakan kebijakan adaptasi perubahan iklim. Peran sektor swasta disini ditekankan pada kontribusi aktivitas dan keuangan untuk upaya adaptasi perubahan iklim melalui program corporate sosial responsibility.

2021 FIA UB. All rights reserved. 


\section{Introduction}

Indonesia is one of the largest emitters of greenhouse gases (later on called GHG) globally. Based on data from the Climate Change Performance Index (CCPI, 2018), Indonesia ranks 7 th out of $20 \mathrm{GHG}$ producing countries in the world. In 2020, Indonesia had become a country with a low contribution to GHG due to the pandemic. However, Indonesia's contribution as a GHG emitter increases again in 2021, in line with the new normal policy. Over the last two decades, GHG emissions have increased in almost all sectors, such as land use, energy, agriculture, industry, and waste sectors. Currently, the forest fire sector dominates GHG emissions in Indonesia, followed by FOLU (food and land use), waste, agriculture, IPPU (industry and product use), and energy (BPS, 2019). WRI (2017) analysis shows that GHG from the energy sector is projected to increase to more than 50 percent of total emissions in 2026-2027.

GHG has created a greenhouse effect which simultaneously causes global warming, and climate change, which leads to an increased risk of disasters. Indonesia and 194 other countries have made commitments to reduce $\mathrm{CO} 2$ emissions, strengthen resilience and adaptation, and join together in real action to combat climate change through the Paris Agreement agenda. One of the Paris Agreement's core points is to prevent the increase in the average temperature of the earth below 2 degrees Celsius and try to limit the increase to below 1.5 degrees Celsius. The equivalent of $32 \mathrm{Gt}$ of $\mathrm{CO} 2$ emissions must be cut and reduced by 2050 to achieve the Paris Agreement's core points. This effort will require an additional investment cost of US $\$ 40$ trillion to be able to make the transition to a low-carbon economy (JMC, 2017). The long-term goal of the Paris Agreement is "net zero-emission" after 2050.

To carry out the Paris Agreement agenda, Indonesia has submitted an INDC (Intended Nationally Determined Contribution) proposal that contains Indonesia's commitments divided into two, under the conditions of un-conditionality and conditionality. Under the conditions of un-conditionality, Indonesia is committed to reducing emissions by up to $29 \%$ compared to the business as usual (BAU) projection scenario in 2030, as a target for emission reduction based on the results of the assessment carried out in 2010 for the National Action Plan for GHG Emission Reduction (RAN-GHG). Meanwhile, under conditions of conditionality, Indonesia will reduce its national emissions by using international assistance with a $41 \%$ reduction in emissions by 2030 .

Adaptation is one of the core points written in the INDC. Climate change adaptation responds to climate change by adapting to current or expected conditions and the desired effects (IPCC, 2014). Climate change adaptation is implemented simultaneously with climate change mitigation. For humans, adaptation aims to reduce or avoid harm and take advantage of opportunities. As for the natural system, humans need to step in to help with the adjustment. Adaptation action can be either incremental action or transformational action. Incremental action is an activity where the main objective is to maintain the system's essence and integrity. Transformational actions change the fundamental attributes of the system in response to climate change and its impacts (IPCC, 2014).

As a country located on the equator and is an archipelago, Indonesia has more vulnerable to climate change. Extreme weather caused by climate change has affected several areas in Indonesia, such as drought, forest and land fires, floods, landslides, sea-level rise, and extreme sea waves. The community is the most affected and vulnerable to the effect of climate change. It is needed to create adaptation strategies in the short, medium, and long term plan to protect communities and to ensure the sustainability of development, mainly to prevent massive socio-economic losses in the future. The Indonesian government commits to anticipate potential negative impacts by preparing the National Action Plan for Climate Change Adaptation (RAN API) or the National Adaptation Plan (RAN) as the primary reference in climate change adaptation. Adaptation is a collaborative effort of various stakeholders and collaboration between the national government, local governments, the private sector, development partners, and communities. It is hoped that the development of climate resilience can support the achievement of national development targets that are sustainable and adaptive to climate change (Bappenas, 2019). This study analyzes how the Indonesian government has carried out environmental governance to adapt to climate change.

\section{Discussion}

\subsection{Climate Change and Environmental Problems in Indonesia}

There are at least ten environmental problems in Indonesia that are still become extensive work for the government and need joint solutions. These environmental problems include river pollution, global warming, forest destruction, global warming, garbage, flooding, damage to marine ecosystems, air pollution, problems with clean water, abrasion, and soil pollution. Indonesia's environmental condition is exacerbated by climate change that has worsened Indonesia's environmental conditions. Not only Indonesia, climate change had become a significant challenge facing the world today. The main factor in climate change is greenhouse gas emissions, which mostly come from energy production and consumption, agriculture, and other ecological processes. The main drivers that cause emissions are global socio-economic activities. Highincome countries are responsible for most of these 
emissions, with the US and Europe releasing 51 percent of total greenhouse gases into the atmosphere (Dow \& Downing, 2006). Low and middle-income countries are considered to be more vulnerable to climate change impacts than high-income countries because of their high dependence on natural resources and low capacity to adapt (Awuor, Orindi \& Adwera, 2008). Increasing climate change threatens decades of development and poverty reduction efforts achieved so far in most countries. Climate change has created an increasing number of disasters in Indonesia (Figure 4). Besides, climate change has a terrible impact on Indonesia, especially in the food security and fisheries sectors. The drought that occurred in Indonesia changed cropping patterns which resulted in crop failure. Also, climate change has changes ocean currents and causes ocean acidification, causing a decrease in fish catches (Ditjenppi, 2020).

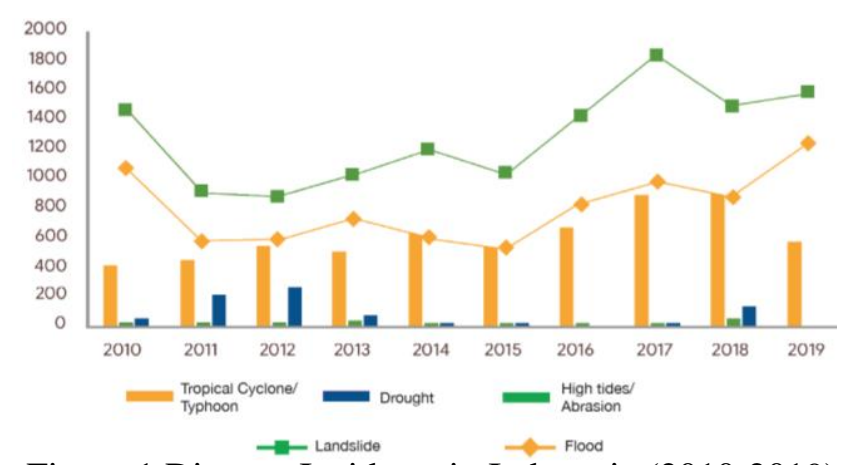

Figure 1 Disaster Incidents in Indonesia (2010-2019)

Source: Author analysis based on BNPB Infographics 2010-2019

There has been an increasing number of efforts to mitigate climate change and reduce its impact at the national, regional, and international levels (Onuoha, 2010). The Kyoto Protocol and the United Nations Framework Convention on Climate Change (UNFCCC) play the most critical roles in tackling climate change at the international level (UNCED, 1992). However, after two decades of the Brundtland Report, there is still no improvement in the results against the key indicators that have come to the fore (WCED, 1990). Indonesia itself has established the RAN API (National Action Plan - Climate Change Adaptation). Bappenas is trying to make climate change adaptation efforts focusing on four sectors achieved in the 2020-2024 period: the agricultural sector, the water sector, the health sector, and the marine sector. Particularly in the environmental sector, the Ministry of Environment has drafted a Regulation of the Minister of Environment P.33 / Menlhk / Setjen / Kum.1 / 3/2016 concerning Guidelines for Climate Change Adaptation and Ministerial Regulation P.84 / Menlhk / Setjen / Kum. $1 / 11 / 2016$ on Proklim. This Ministerial Regulation aims to provide guidelines for the central government and local governments in formulating climate change adaptation actions and integrating them into the development plans of a specific region and/or sector. The specific sectors referred to include food security, energy independence, health, housing, infrastructure, and coastal and small islands. At least four stages are carried out, namely: (a) identification of target coverage of specific areas and/ or sectors and the problem of climate change impacts in an area; (b) preparation of climate risk and vulnerability assessments; (c) quality control of climate change documents; and (d) setting priorities for climate change adaptation actions and integrating climate change adaptation actions into development.

\subsection{Environmental Governance and the Urgency of Climate Change Adaptation}

The poor and vulnerable groups are the most affected by climate change, such as floods, drought, and other weather events (IIED, 2020). Climate change adaptation efforts will help individuals, communities, organizations, and natural systems deal with the inevitable consequences of climate change. This involves taking practical action to manage risks from climate impacts, protect communities and strengthen economic resilience. Adaptation can involve gradual transformations with many small steps over time or significant transformations with rapid changes. Adaptation is a shared responsibility. Governments at all levels, business groups, and households each have a complementary role in this endeavor. In the Regulation of the Minister of Environment P.33 / Menlhk / Setjen / Kum.1 / 3/2016 concerning Guidelines for the Compilation of Climate Change Adaptation, climate change adaptation must be prepared involving stakeholders consisting of at least government agencies, universities, and representatives from the local community.

Government agencies acting as the coordinator, data provider, and formulator of using the assessment results or vulnerability/ risk assessment of climate change impacts and strategies for recommended adaptation measures to be mainstreamed into development programs in the regions. University is an academic institution that can carry out assessments or studies that include analysis of the impacts, vulnerabilities, and risks of climate change in a region and various sectors, formulating steps of climate change adaptation action and supervising, and evaluating the implementation of adaptation action to climate change. University can also organize training to increase government staff's capacity in understanding the stages of assessing climate change vulnerability/risk and using the results for the preparation of adaptation actions. Meanwhile, local community representatives are independent institutions formed by non-profit communities with concerns on issues relevant to mitigating climate change impacts (environmental, humanitarian, development, etc.). This element's role is 
as a party that can help verify needs in the field, connect vulnerable community groups, increase the capacity and empowerment of communities and local authorities, support implementation efforts, and ensure transparency and accountability of the planning process and implementing adaptation efforts. Stakeholder involvement can be developed in accordance with the needs and conditions of a specific region and/ or sector.

The stakeholder's involvement in the preparation of climate change adaptation can be formed as a working group that focuses on climate change adaptation which generally has the following duties and functions:

a) Collecting and interpreting the necessary information related to the vulnerability/ risk of climate change in a region or sector and periodically monitoring the contribution of adaptation efforts made to the vulnerability/ risk profile of a specific region or sector;

b) Design adaptation options based on climate change vulnerability/ risk assessments or technically feasible assessments consistent with local development objectives and critical policy criteria (costeffectiveness, environmental sustainability, culturally appropriate, and socially acceptable);

c) Mainstreaming adaptation measures into climate change adaptive development programs by formulating climate change adaptation policies, strategies, programs, and activities and ensuring the synergy of adaptation efforts and achieving development targets;

d) Responsible for the internal coordination process and coordination/ cooperation with external parties related to climate change adaptation activities;

e) Encouraging strong cooperation between communities, government, academia, and the general public to support climate change adaptation efforts;

f) Promote the implementation of climate changeadaptive development programs so that the technical aspects of adaptation actions receive adequate support from relevant government institutions; and

g) Perform periodic documentation and reporting.

The working group's membership composition above can be adjusted to a specific region and/ or sector's conditions and needs. The organizational system (hierarchy) and the membership structure's responsibilities are also adjusted to the governance that applies to the scope of the study.

\subsection{Environmental Governance and Climate Change Adaptation in Indonesia}

Indonesia has created and implemented policies and programs to fight climate change. These policies and programs aim to reduce the impact of climate change and establish domestic sectoral targets through passing laws and regulations. a) National Emission Reduction Goals

As a commitment to reducing national emissions, President Susilo Bambang Yudhoyono announced Indonesia's voluntary goal to reduce GHG emissions during the Group Summit of 2009. This goal is to reduce GHG by 26 percent in the business as usual and 41 percent with international support. In 2011, the target was submitted as a mitigation action by the Indonesian government to the UNFCCC. Indonesia then issued Presidential Regulation No.61 of 2011 concerning the National Action Plan for Reducing Greenhouse Gases (RAN-GHG) as a total commitment to achieving the stated mitigation goals. Indonesia then submitted its Intended Nationally Determined Contributions (hereinafter referred to as INDC) to The United Nations Framework Convention on Climate Change (UNFCCC) in 2015. INDC is a document designed and prepared by the Ministry of National Development Planning (BAPPENAS) to translate Indonesia's commitment to reducing climate change impacts. In the same year, the Government of Indonesia signed and ratified the Paris Agreement and restated these targets in the proposed nationally determined contribution (INDC). The Paris Agreement is an agreement in the United Nations Framework Convention on Climate Change (UNFCC) that safeguards the effective reduction of carbon dioxide emissions and comes into force in 2020.

b) National Policy and Sectoral Target

The Indonesian government has issued at least several laws, decrees, and government regulations on efforts to comply with climate commitments and sectoral targets, which include:

1) Presidential Regulation of the Republic of Indonesia Number 61 of 2011 concerning the National Action Plan for Reducing Greenhouse Gas Emissions

This regulation places RAN-GHG as the basis for implementing various mitigation actions. The National Action Plan for Greenhouse Gas Emission Reduction (RAN-GRK) is a work plan document for implementing various activities that directly or indirectly reduce greenhouse gas emissions following national and regional development targets. RAN-GRK activities include agriculture, forestry and peatlands, energy and transportation, industry, waste management, and other supporting activities. Some of the other vital points of this rule are as follows:

- RAN-GRK is a guideline for Ministries and Institutions in planning, implementing, monitoring, and evaluating GHG emission reduction action plans, as well as guidelines for local governments in preparing Regional Action Plans-Greenhouse Gas (RAD-GRK) 
- To reduce GHG emissions in each province, the Governor must prepare RAD-GRK based on RAN-GRK and regional development priorities.

- RAN-GRK can be reviewed periodically following national needs and developments in international dynamics

2) National Medium Term Development Plan; RPJMN

The commitment to reduce greenhouse gases has also been implemented by affirming sustainable development in preparing the 2010-2014 Medium Term Development Plan (RPJMN). The 20102014 RPJMN states that climate change is a crosssectoral program, which means that several sectors have activities to deal with climate change. GHG emission reduction is determined for five priority sectors: agriculture, energy and transportation, solid waste, forestry and peatlands, agriculture, and solid waste). Meanwhile, in the preparation of the 2020-2024 RPJMN, Bappenas emphasizes green growth and low-carbon development, which will be accommodated through the Strategic Environmental Assessment process in the RPJMN 2020-2024 formulation process. The 2020-2024 RPJMN places the environment's carrying capacity and natural resources (SDA) as the primary concern of development.

3) Presidential Decree No. 16 of 2015 concerning the Ministry of Environment and Forestry

The Indonesian government's efforts to address the impacts of climate change are to form the National Council on Climate Change or DNPI (through Presidential Decree 46 of 2000) and the REDD + Management Agency (Reducing Emissions from Deforestation and Forest Degradation, the role of conservation, sustainable management of forest and enhancement of forest carbon. stocks in developing countries) through Presidential Regulation No. 23 of 2013. At the end of 2014, the Ministry of Environment and the Ministry of Forestry were merged. Through Presidential Decree Number 16 of 2017, the Ministry of Environment and Forestry was formed. Under the new Ministry, the National Council on Climate Change (DNPI) and the REDD + Agency were then placed under the Directorate General of Climate Change Control within the Ministry of Environment and Forestry.

The Directorate General of Climate Change Control (DJPPI) is one of the work units of the Ministry of Environment and Forestry which deal with climate change, especially in the implementation of mitigation, adaptation, reduction of greenhouse gas emissions, reduction and elimination of ozone-depleting substances, resource mobilization, and inventory of greenhouse gases, monitoring, reporting and verification of climate change mitigation actions and controlling forest and land fires. With the establishment of the DJPPI, it is new hope for implementing well-managed climate change control activities in support of development goals in the environmental and forestry sectors.

4) Presidential Instruction No. 6 of 2017 concerning the Postponement and Refinement of Governance for the Granting of New Permits for Primary Natural Forests and Peatlands

President Jokowi issued this instruction to complete various efforts to improve primary forest and peatland governance. These efforts are in progress to reduce emissions from logging and forest loss. These detailed instructions include:

- to the Ministry of Environment and Forestry: to seek to reduce emissions from forests and peatlands. This instruction is carried out through improving the management of proposed business activities in forests and peatlands as stipulated in the Indicative Map for Suspension of New Permits (PIPIB) through environmental permits.

- to Governors and Regents/ Mayors: postpone the issuance of recommendations and new location permits for forest and peatland areas as well as areas for other uses based on PIPIB

- PIPIB renewal in forest areas and other use areas is carried out every 6 (six) months by the Head of the Geospatial Information Agency, collaborating with the Minister of Environment and Forestry and the Minister of Agrarian Affairs and Spatial Planning/ Head of the National Land Agency.

5) Presidential Regulation Number 120 of 2020 concerning the Peat and Mangrove Restoration Agency

Indonesia alone accounts for $47 \%$ of the world's tropical peatlands and is the fourth country to have the world's largest peatlands. In the last twenty years or so, the conversion of peatlands to agricultural land, oil palm plantations, and pulpwood has destroyed peatlands with all their ecological functions.

From June to November 2015, there were forest and land fires in Indonesia. According to the World Bank, the loss was estimated at 221 trillion rupiahs. In general, these fires occur on the islands of Sumatra and Kalimantan.

The Indonesian government in 2016 formed the Peatland Restoration Agency and was renamed by the Peat and Mangrove Restoration Agency of the 
Republic of Indonesia (hereinafter referred to as BRGM). BRGM is a non-structural institution that is under and responsible to the President. BRGM is tasked with facilitating the accelerated implementation of peat restoration and improving community welfare in peat restoration areas, and accelerating mangrove rehabilitation in target provinces.

6) Government Regulation No. 79 of 2014 concerning National Energy Policy

Through Government Regulation Number 79 of 2014 concerning National Energy Policy, the Indonesian Government encourages the use of New and Renewable Energy (EBT) and puts a brake on the use of fossil energy sources. The policy has set a target for the EBT mix from 2020 to 2050 .

Government Regulation No. 79/2014, a derivative of Law No. 30 of 2007, is one way to build energy security by creating national energy reserves consisting of operational reserves, energy buffer reserves (CPE), and strategic reserves. However, this policy still receives criticism because it uses fossil fuels as primary energy even though it has set a target of using renewable energy at least $23 \%$ of total energy in 2025 and at least $31 \%$ in 2050 . in the EDSM document, namely "The White Paper of the 5000 MW PLTN (update Feb. 11, 2015) on page 9, it is written that it is estimated that the national petroleum reserves will be exhausted within 12 years. So that proven coal reserves are estimated to be exhausted within 22 years. Most of the gas is still being exported and is expected to run out within 36 years. Meanwhile, most renewable energy is intermittent energy, meaning that energy is not continuous, such as wind and solar, meaning that it cannot be used as a mainstay of primary energy. The intermittent source of energy must often be hybridized with fossil energy such as diesel and gas, which in turn makes it uneconomical but is still forced because of the international agreement on clean energy.

7) RAN-GHG: Approach to Climate Change Adaptation in Development Planning Perspective For developing countries, especially Indonesia, climate change adaptation is no longer an option but a priority for sustainable development. Therefore, the involvement of all stakeholders must be inclusive and efficient. As a national strategic plan, RAN API has four priority sectors for climate change adaptation: marine and coastal, water, agriculture, and health. In implementing climate resilience development in these priority sectors, there are 4 (four) adaptation strategy clusters (infrastructure, technology, capacity building, and governance). Clusters need to take into account (inherent) gender sensitivity and vulnerable groups, ecosystem-based, landscapebased or spatial, and financial innovations. The RAN API identifies priority adaptation programs and provides policy mechanisms that can be modified to be more climate-resilient. The RAN API also provides priority location directions for climate change adaptation actions. Based on the analysis of the Data Vulnerability Index Information System (SIDIK), there are 98\% of areas (villages) with medium-high vulnerability. Sharing information between stakeholders is an essential part of this process. All adaptation action plans will be reviewed and updated frequently.

Besides, the RAN API document must include a monitoring and evaluation mechanism, the results of which can be used as feedback for ongoing processes and used to update the RAN API or other related plans periodically. The RAN API is part of Indonesia's national development planning framework. In terms of national development planning, RAN API acts as a special cross-sectoral plan for climate-resilient development. Thus, the objective of the RAN API's priority activities is to strengthen the strategic plans of each institution in climate change adaptation. At the national level, the RAN API acts as a guideline or reference that provides direction for future Government Work Plans to respond to the impacts of climate change. At the regional level, the RAN API acts as a reference for local governments to prepare Regional Action Plans/ Strategies and deal with climate change.

c) Monitoring and Evaluation System

Evaluation is the primary measurement instrument that shows the process of implementing climate change adaptation. Climate change adaptation evaluation is carried out annually by monitoring (continuous), in the medium term, and at the end of the document development planning period (ex-post). The final evaluation of the adaptation process is critical for countries to know how to reduce economic losses due to climate change. Climate change adaptation programs and activities will be monitored and evaluated through the climate budget tagging system, both from the APBN (State Budget) source and the Climate Change Registry System made by the Ministry of Environment and Forestry.

1) Climate budget tagging

The climate budget tagging from state budget (APBN) sources aims to monitor and evaluate the APBN allocations and activities' effectiveness. This act is a form of transparency and accountability of climate activities to the public. 
All parties involved in marking the climate budget are government agencies that have APBN resources. Every government agency must tag all climate programs, activities, and outputs on the Ministry of Finance website. Currently, the Ministry of Finance is developing a climate budget tagging system for local government budgets for climate change activities. Thus, all local governments can tag climate change programs and activities on the Ministry of Finance website live.

2) National Climate Change Registration System The National Climate Change Registration System (SRN) involves all stakeholders, such as government agencies, local governments, research institutions, NGOs, development partners, universities, philanthropists, the private sector, indigenous peoples, and other community groups. The SRN has been ratified through the Minister of Environment and Forestry (KLHK) Regulation Number 72 of 2017. The SRN can be accessed through the website of the Ministry of Environment and Forestry. The components listed in the SRN include (1) climate change adaptation policies; (2) scientific studies; (3) climate change adaptation planning; (4) implementation of activities; (5) monitoring and evaluation; and (6) capacity building. Meanwhile, the scope of monitoring and evaluation of the RAN API (RAN) from the SRN list includes:

- suitability of activity options with the level of vulnerability,

- the period for achieving the target of adaptation activities,

- achievement of objectives by comparison of planning indicators/ targets.

d) Clusters in Climate Change Adaptation

1) Climate-resilient Infrastructure

In adaptation, infrastructure must be climateresilient, ecosystem-based, and retrofit to face the challenges and impacts of climate change (Bappenas, 2019). It should be a more green infrastructure rather than a gray infrastructure. Gray infrastructure is artificial facilities using pavement designs, such as concrete or non-natural buildings. In contrast, green infrastructure is built in harmony with the landscape or using environmentally friendly and inexpensive technology for maintenance. Moreover, the infrastructure should develop by considering the solid local knowledge base about climate variability and climate change's possible impacts. Infrastructure needs to support multi-hazard and risk reduction. Infrastructure must pay attention to low-income people and vulnerable groups because they are most vulnerable or at risk of climate change. Infrastructure development must integrate with the national development plan, SDGs, and poverty reduction strategic plans.

2) Capacity building

Capacity Building in Climate Change encourages stakeholders to design and implement actions to reduce climate change impacts, adapt, address loss and damage, organize credible steps to monitor climate-related parameters, adopt new technologies and methods, and raise awareness of climate change.

3) Climate-resilient technology

Technology is a scientific method for practical needs in addressing the potential impacts of climate change on humans and the environment. Technology can also be used to benefit from the positive effects of climate change. Adaptive technology that can respond to climate change's potential impacts and in line with development goals is cost-effective, environmentally friendly, culturally appropriate, and socially acceptable.

4) Climate Change Adaptation Governance

Governance is related to regulations, institutions, and coordination strategies for adaptation efforts in the pillars of development, both government, private, and community. Governance requires mechanisms and instruments to support adaptation efforts, namely policy and operational instruments, such as regulations and information systems. Good governance is implemented through the coordination of development pillars by applying the principles of inclusion, transparency, easy access to information, and accountability.

e) Adaptation targets

In efforts to adapt to climate change, the Government of Indonesia is committed to protecting society and the environment from climate change impacts, which will simultaneously bring benefits and improve people's lives and ecosystems. To avoid economic losses, policymakers must make various efforts not only for mitigation but also for adaptation. According to economic valuation, adaptation efforts can avoid national GDP losses from 24.43 thousand trillion (without adaptation action) to 24.49 thousand trillion (with adaptation actions) by 2024. The scenarios and planned efforts in climate change adaptation will bring significant benefits, especially in terms of the economy.

f) Action Plan

The development of climate resilience is an obligation to protect the community and various other aspects of development from the threats and risks of climate change. This effort benefits the sustainability of economic, social, and environmental life, considering that Indonesia is an agricultural country and has the 
second-longest coastline in the world. Indonesia aims to achieve ideal climate resilience conditions with a solid anthropological and ecological system that is resilient to the dangers of climate change. As contained in the RAN API document, it requires integrated support from policies and other strategic or planning documents to achieve the RAN API targets to reduce climate change impacts. The participation of various stakeholders, namely central and local government, the private sector, development partners, and the community, is urgently needed. To ensure the involvement of stakeholders, specific policies are needed that can provide incentives for all stakeholders, especially the private sector and individuals, to have a common will towards a climateresilient economy. There are four priority sectors in implementing this action plan, namely the water resources sector, the agricultural sector, the marine and coastal sector, and the health sector. Adaptation action in each priority sector involves various stakeholders, including central and local governments, who have direct authority regarding the priority sector. To develop adaptation actions, each priority sector has a specific delivery strategy and strategy (indicative intervention).

g) Resource Mobilization Mechanisms and Coordination The RAN API document is a long-term planning document to support the Sustainable Development Goals (SDGs) achievement in 2030 and Indonesia's Vision 2045. Implementation of the RAN API considers and synergizes the process with other strategic policy documents, namely SDGs, disaster risk reduction, spatial planning, and low-carbon development which has direct and indirect benefits for amplifying climate change adaptation actions. An inclusive and iterative approach is applied in preparing the RAN API by understanding the affected sectors' characteristics through experiences and best practices at the local level. The financial mechanism for climate change adaptation is from the APBN (state budget), APBD (local budget), international mechanism, private investment, and Corporate Social Responsibility (CSR). International sources of funding are available to governments, the private sector, and communities. Adaptation efforts need to be mainstreamed in all affected development sectors. Proactive government (national and local) and other stakeholders (private sector, development partners, and communities) are essential to support these efforts.

\subsection{Streghtening Environmental Governance for Climate Change Adapttation in Indonesia}

Several things need to be strengthened in implementing climate change adaptation, including government commitment, involvement of the private sector, and funding in this effort

\subsubsection{Government Commitment}

Indonesia has ratified the Paris Agreement at the international level and has committed to reducing GHG emissions with two major schemes. However, policy frameworks and implementation often do not go hand in hand because not all local governments are pursuing plans as stated. The climate change mitigation and adaptation budget may be spread across various other Ministries/ Agencies. However, the Ministry of Environment and Forestry does not even include one of ten ministries and agencies with the largest budget in 2020. APBN 2020 by the Ministry of Finance shows that environmental protection only gets an allocation of $1.1 \%$ (Rp. 18.4 trillion) of the total national budget. Most countries, including Indonesia, are not ready to face climate change. A report by the World Health Organization (WHO) examines the readiness of 101 countries in the face of extreme weather events, such as floods, drought, and heatwaves. The report shows that only half of these 100 countries have climate change and health strategies. Of these, only 38 percent have allocated financing, and less than 10 percent have implemented and funded their plans. Here, a commitment from the central and local governments is needed in implementing climate change adaptation plans.

\subsubsection{Private Sector Involvement in Climate Change Adaptation Efforts}

A recent research report from the IPCC confirms that we need to strengthen ambition and enhance cross-sector collaboration to tackle climate change's worsening challenges. Indonesia's NDC emphasizes the importance of engaging the role of non-government, including the private sector, in climate fighters' ranks. Through innovation and new technology owned by the private sector, Indonesia can increase its climate commitment. Until now, the role of the private sector in climate change adaptation has been sectoral and partial. A synergistic pattern of private sector involvement is needed to implement environmental governance in climate change adaptation efforts. The challenges of private sector involvement in adaptation projects are generally due to marginal returns on investment and a lack of awareness of the risks of climate change impacts. Although companies take proactive action to achieve the full benefits of low-carbon development, the government also needs to support its implementation through regulatory review measures, avoiding layered reporting systems, providing incentives and funding for climate change adaptation. For the private sector to implement clear and measurable policies, a coherent regulatory framework must be established. Not only is it detrimental to relevant 
stakeholders, but conflicting policies issued by various institutions also have the potential to create a bottleneck in efforts to enhance the climate agenda. The initial step that must be taken immediately is to review the current policy to identify constraints and necessary improvements.

To date, the Government of Indonesia has used three different platforms to compile company emission profiles based on different mandates and objectives (SiINAS, PROPER, and POME). Under this system, companies are required to report their activities to the three platforms above every year. Given the similarities in the databases collected by these platforms, this system is unlikely to be effective. Finally, the private sector is burdened with overlapping reporting obligations, while the government has to put more effort into data validation. The existence of a platform that is integrated with accurate and up-todate corporate climate action data will undoubtedly be very useful in directing Indonesia's climate change mitigation efforts.

\subsubsection{Funding to Tackle Climate Change}

Funding to tackle climate change in Indonesia comes from three things. First, domestic financing through the state budget allocation. The second is in the form of grants or loans from abroad. Both are included in the state budget recording and have legal consequences in accordance with the prevailing laws and regulations in Indonesia. Third, the source of funds from the private sector. For example, from the banking or non-bank sector, Corporate Social Responsibility (CSR), potential investment from the private sector, etc. which are expected to become policy incentives to support mitigation efforts.

Through Government Regulation no. 38 of 2007 concerning the Division of Government Affairs between the Government, Provincial Government, and District/ City Government, also states that environmental affairs also include government affairs which are shared between levels and/ or structures of government from the central, provincial and district governments/ city, Allocated through DAK. The laws and regulations show Indonesia's commitment to tackling climate change, in terms of commitment to putting the issue of climate change as a cross-cutting issue in national development, including its financing. In fact, this commitment starts from the constitution as the highest legal basis to implementing technical regulations.

A Presidential Decree regulates foreign grants and loans related to climate change financing included in the APBN implementation cycle; this follows the provisions of Article 26 of the Law on State Finance. Following the provisions of Article 41 PP No.10 of 2011, foreign loans related to climate change financing also have consequences for repaying either interest or principal loans. The Minister of Finance is responsible for paying according to the allocations contained in the APBN; this payment process also involves Bank Indonesia.

As with foreign loans, climate change financing sourced from grants also follows the flow set by the APBN. The minister of finance monitors the realization of the grant-sourced budget, while the minister for national development planning / the head of the National Development Planning Agency will monitor the realization and progress of activities originating from this grant. If the absorption of the budget originating from foreign loans or grants is low, then the finance minister can request the cancellation of part or all of the foreign loan or grant agreement.

\section{Conclussion}

The global climate change model predicts that all Indonesian regions will experience temperature increases, including sea surface temperatures, which increase and change the pattern and intensity of rainfall, increasing the risk of flooding and drought in the dry season. This has the impact of, among others, prolonged drought, floods, an increase in the frequency of extreme climatic events that affect people's health and livelihoods as well as biodiversity and economic stability, which in turn can increase threats to the achievement of Indonesia's socio-economic development. Adaptation efforts and strategies, both in the short, medium, and long term, are felt necessary to protect the most impoverished communities and avoid more significant economic losses in the future due to climate change. In Indonesia, climate change's economic impact is estimated to be very large, although it is still difficult to calculate with certainty. National development with an adaptation agenda to the impacts of climate change has the ultimate goal of creating a development system that is adaptive or resilient to current climate change. To anticipate the negative impacts of climate change, the Government of Indonesia has made various efforts to adapt to climate change, including the preparation of national policy documents to address the impacts of climate change, such as the Indonesia Adaptation Strategy, the Indonesian National Action Plan for Climate Change Adaptation, Indonesia Climate Change Sectoral Road Map, National Action Plan for Facing Climate Change, and sectoral adaptation plans by Ministries / Agencies. A Strategy Document for Mainstreaming Adaptation in National Development Planning has also been prepared. However, many adaptation activities in sectors can need and must be synergized with other sectors and integrated into development planning and budgeting (RPJMN and RKP) to be adaptation targets achieved and resilient to the impacts of climate change can be increased. At least three things need to be considered to increase the capacity of governance for climate change adaptation for Indonesia, 
namely capacity building and synergy between governments, intensive involvement of the private sector, and involvement of multilevel governance.

\section{References}

Awuor, Cynthia B., Orindi, Victor A., \& Adwera, Andrew O. (2008). Climate Change and Coastal Cities: The Case of Mombasa, Kenya. Environment and Urbanization, 20(1), 231-242.

Bappenas. (2019). National Adaptation Plan: Executive Summary. Jakarta: Bappenas.

BPS. (2019). Emisi Gas Rumah Kaca menurut Jenis Sektor (ribu ton CO2e), 2001-2017. Accessed from <https://www.bps.go.id/statictable/2019/09/24/20 72/emisi-gas-rumah-kaca-menurut-jenis-sektorribu-ton-co2e-2001-2017.html>

CCPI. (2018). Climate Change Performance IndexResult 2018. Germanwatch, Germany.

Ditjenppi. (2020). Perubahan Iklim di Indonesia. Accessed from $<$ http://ditjenppi.menlhk.go.id/kcpi/index.php/info -iklim/dampak-fenomena-perubahan-iklim/229perubahan-iklim-di-indonesia>

Dow, K., \& T Downing. (2006). The Atlas of Climate Change. Earthscan, London.

IIED. (2020). Community-based adaptation. Accessed from <https://www.iied.org/community-basedadaptation?gclid=EAIaIQobChMIms7h6ryH6gIV IDUrCh11nQ9rEAAYASAAEgJr9fD_BwE>

IPCC. (2014). Adaptation needs and options. Geneva: IPCC.

JMC. (2017). Kebijakan Perubahan Iklim dan Aksi Mitigasi di Indonesia. Accessed from $<$ http://jcm.ekon.go.id/en/uploads/files/Document $\% 20 \mathrm{JCM} /$ Presentation/Workshop\%20Forum\%20J CM\%20untuk\%20Kemitraan\%20Pembangunan\% 20Rendah\%20Karbon\%20di\%20Sumatera\%20Ut ara_230816/(1)_Dicky_kebijakan_perubahan_ikli m di Indonesia.pdf $>$

Onuoha, F. C. (2010). Climate Change, Population Surge and Resource Overuse in Lake Chad Area: Implication for Human Security in the North-East Zone of ni9geria in Donald Anthony Mwiturubani and Jo-Ansi Van Wyk 's Climate Change and Natural Resource Conflicts in Africa Pages 85-103 in K. Bakker, editor. Eau Canada: the future of Canadian water governance. University of British Columbia Press, Vancouver.

UNCED. (1992). Agenda 21, Unted Nations Conference on Environment and Development. Geneva: UNEP.

World Commission on Environment and Development WCED. (1990). Our Common Future, Australian edn. Oxford University Press, Melbourne.

WRI. (2017). How Can Indonesia Achieve Its Climate Change Mitigation Goal? An Analysis of Potential Emissions Reductions from Energy And Land-Use Policies. Accessed from $<\mathrm{https} / / /$ wri-
indonesia.org/sites/default/files/WRI\%20Layout \%20Paper\%20OCN\%20v7.pdf> 